\title{
14. Rhino systematics in the times of Linnaeus, Cuvier, Gray and Groves
}

\author{
Kees Rookmaaker
}

\section{History inspires innovation}

Most scientists agree that it is imperative to read the literature in their immediate field of interest hot off the press to keep abreast of the latest advances. They build on a more extensive body of knowledge which is the result of past explorations and discoveries by persons working in the same discipline. Generally it is almost irrelevant how the current consensus was reached or which people were responsible for it, unless a discovery or theory represented a major breakthrough. The history of a given subject is of course highly interesting, and any scientist would be advised to pay attention to the lives of their predecessors in their speciality. While for the majority of scientists such historical insight is largely optional, it often appears that students of animal taxonomy have much less choice. Animal and plant biodiversity is so immense that a revision must necessarily take into account all previous studies of the specimens and populations now combined in a certain species or higher ranking group. We are bound to respect the decisions and models of previous generations of taxonomists, although we have every right to fine-tune them or even dismiss them completely.

The historical component of taxonomy is nowadays often as quickly recognised as it is dismissed. Searching old and dusty books, examining skulls and hides in museum storerooms, locating old geographical placenames, understanding obscure concepts of classification, is it really needed to understand the evolutionary species groups? When a bibliographer or historian finds a scientific name which had long remained hidden in some obscure or rarely consulted journal, there is often an immediate call to relegate it to the growing list of 'forgotten names' - names often forgotten merely because the contemporary colleagues of the naturalist who proposed the name had only a partial knowledge of the new literature. Nomenclature may be a part of taxonomy which in its rules has an historical dimension, but taxonomy is one science where history cannot safely be ignored.

Colin Groves is one of those taxonomists who is sensitive to past research. He has shown this in his 2008 book Extended family: Long-lost cousins (a personal look 
at the history of primatology). In the same vein, the present chapter is a personal look, this time mine, at four different phases in the history of the systematic research of the small group of currently existing species of rhinoceros. Given that there are only a handful, or maybe just over a handful of qualifying rhino taxa, the history of the understanding of their relationships is unexpectedly treacherous and complicated, as well as ever changing. As this is a personal look, I have only quoted the most relevant literature in the bibliography. Much has been written about the rhinoceros. In 1983 I bravely published a Bibliography of the Rhinoceros, and was proud to state that I had been able to extract 3,106 references (pleased enough even to count them manually). Continuing ever since to archive the world's output on these animals, the bibliography has now extended to over 18,000 references (fortunately counted by a computer). All these are globally accessible on the Rhino Resource Centre, which provides the references as well as the text on the website: www.rhinoresourcecentre.com, a stable and hopefully not too ephemeral source of information, current as well as historic, on everything related to rhino studies.

Although history does not often allow a saltationary approach, I will focus on just four periods in the story of rhino systematics. This will show how the classification of the living world changed over time, from the mid-eighteenth century to the present.

\section{Rhino systematics in the time of Carl Linnaeus}

\section{Uppsala, Sweden: 1758}

Carl Linnaeus (1707-1778), the famous professor of botany in the small university town of Uppsala, is unlikely ever to have seen a rhinoceros alive. For most of his work on the animal kingdom, he had to depend on occasional specimens in a few collections, and of course on a thorough knowledge of the renaissance literature. Given the enormous scope of his pioneering endeavours to classify all known animals and plants, the results were remarkably fair to the prevailing sentiments of his time. His work was of course highly innovative, which makes it easy to understand that it took him several adjustments along the way to find the right format to fit all available information.

His main work on animals was the Systema Naturae, first published in 1735 and updated through a series of revisions to the most authoritative tenth edition of 1758. Linnaeus masterfully condensed the entire animal kingdom: at first he needed only a pamphlet of just 12 pages, in 1758 expanded to about 800 pages, to 
list all known vertebrates and invertebrates. His list of mammals occupied just 63 pages, nevertheless was remarkably comprehensive. His species were inclusive of all variants, defined strictly morphologically rather than zoogeographically.

This emphasis on morphological and anatomical characters led to some rather surprising results. Because the rhinoceros was known to have incisor teeth, the animal came to be classed together with rodents of the genera Hystrix, Lepus, Castor, Mus and Sciurus, away from other pachyderms or ungulates. But Linnaeus had relied on insufficient evidence, inasmuch as only one of the two species of rhinoceros recognised in his book actually has these incisors. The only type of rhinoceros well-known in his time was the species with a single horn, now known as Rhinoceros unicornis, the Indian or greater one-horned rhinoceros.

There were of course plenty of rumours of rhinos having two horns, both in Asia and in Africa. There were even a number of specimens in European collections where the two horns were still attached to each other and obviously belonged to the same animal. The academic world, for some reason still poorly understood, was reluctant to admit the existence of a second species of rhinoceros, which would have two horns on the nose instead of one. The reasoning at the time was as ingenuous as it was convoluted, with the number of horns being ascribed to climate, age, sex, size, to just about anything except to the possibility that there was more than one species of rhinoceros. In an age when unicorns and dragons were still very much in discussion, this reluctance seems excessive.

Linnaeus was a brave taxonomist. He was certain that there was a rhinoceros species with two horns on the nose, separated from the one with a single horn, but remarkably, he did appear to see the need to explain himself. 'I have seen the complete head of one of these animals', he stated, therefore he could not doubt its existence. However, when we carefully read his paragraphs in the Systema Naturae of 1758, we end up with a species of rhinoceros with two incisors on either side of the jaws, a double horn on the nose, living in India. If Linnaeus actually examined the head which he claimed to have seen, with his extensive knowledge of animal morphology, it must be concluded that he saw a skull of an Indian rhinoceros where a second horn was artificially added to the specimen. If this interpretation is correct, it exonerates Linnaeus, but did nothing to help the study of rhino systematics in the remainder of the eighteenth century. 


\section{Rhino systematics in the time of Georges Cuvier}

\section{Paris, France: 1816-1836}

There were a number of new discoveries in the half century separating the works of Linnaeus and Georges Cuvier (1769-1832), professor of natural history in Paris. The vicinity of the Cape of Good Hope was carefully explored and yielded exhaustive morphological and anatomical descriptions of the resident black rhinoceros by people like Robert Jacob Gordon and Anders Sparrman (Figure 14.1). Travellers in other parts of Asia had long known about the existence of a rhinoceros outside the Indian subcontinent, said to bear either one or two horns on the nose. The evidence soon became overwhelming enough to recognise that changes were needed.

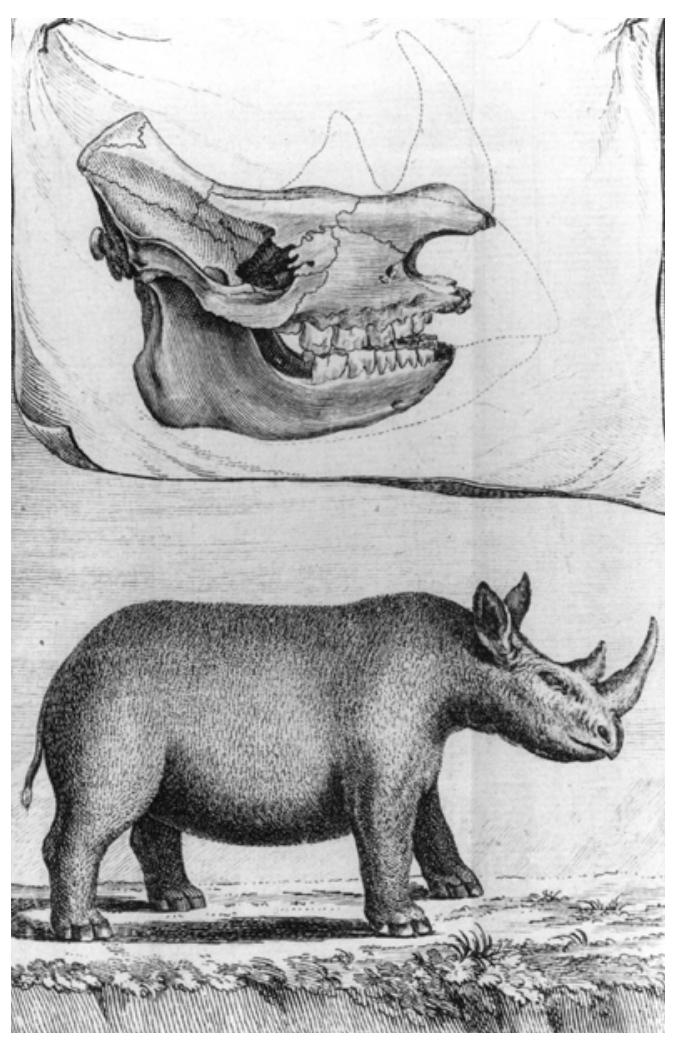

Figure 14.1: Black rhinoceros and skull, sketched by Anders Sparrman after a specimen which he shot in South Africa's Cape Province, December 1775. Published in his Resa till Goda-Hopps-Udden, Stockholm, vol. 1 (1783), plate 5. 


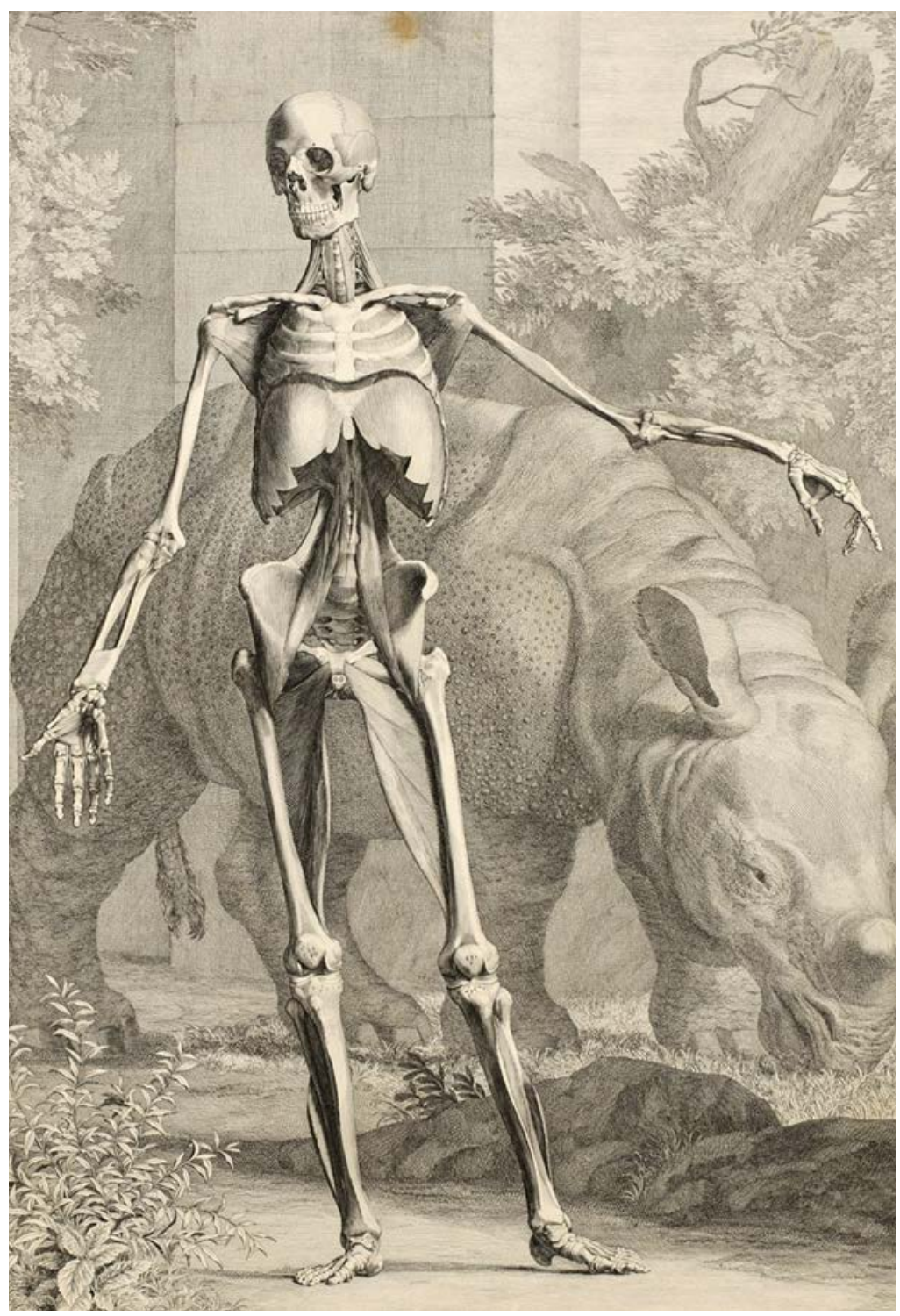

Figure 14.2: The famous Indian rhinoceros 'Clara', shown all around Europe between 1741 and 1758, depicted behind a human skeleton in the anatomical atlas by Bernard Siegfried Albinus, Tabulae sceleti et musculorum humanis corporis (1747), pl. 4.

Source: From Bernard Siegfried Albinus, Tabulae sceleti et musculorum humanis corporis (1747), pl. 4. 


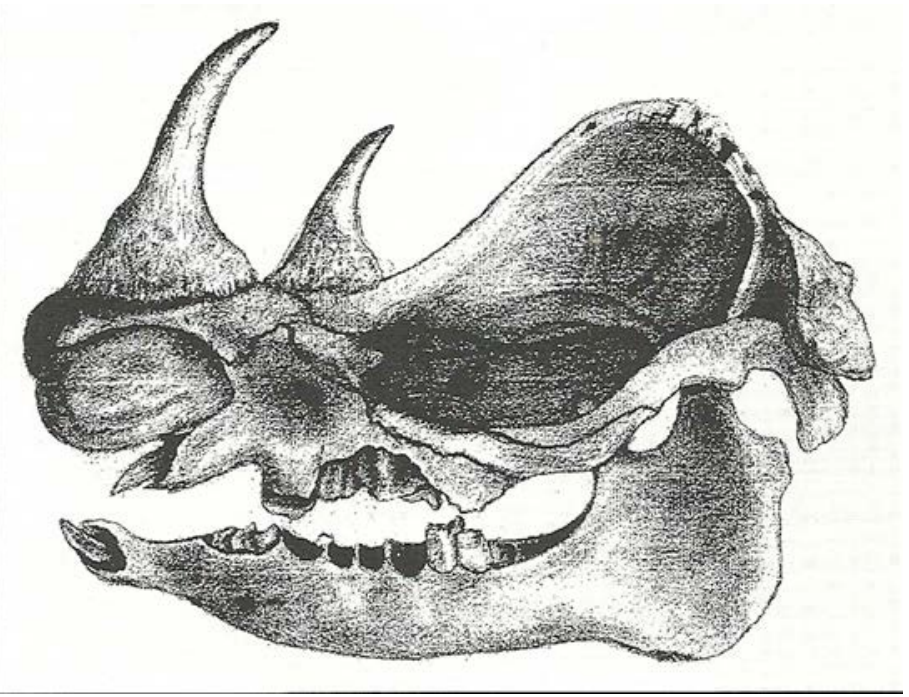

Figure 14.3: A rhinoceros skull drawn by the English physician James Parsons in or near London in the early eighteenth century. It is an Indian rhinoceros (Rhinoceros unicornis) with incisors, indicating that the posterior horn must have been an artificial addition.

Source: Hunterian Library, Glasgow, Av.1.17 folio 13.

William Bell (d.1792), trained as a zoological draughtsman by the great collector John Hunter in London, spent a few months in the British Fort Marlborough on the west coast of Sumatra. Some 10 miles away from the town, he found a rhinoceros, made drawings, collected the skull, and sent all off with a useful description to London, where his work was duly published by the Royal Society. Hence the existence of Rhinoceros sumatrensis could no longer be doubted.

Rhino specimens sent from Java had already convinced Petrus Camper (17221789 ) in the 1780s that this animal really differed from the better known singlehorned rhinoceros. Camper was not only a famous professor of human anatomy, but he was also interested in the morphological structures of the larger mammals like reindeer, orangutan, elephant and rhinoceros. At the end of his life, his studies convinced him that the rhinoceros of Java differed materially from the other species. Although possibly his death kept him from writing a treatise on the subject, he did engage a local artist to show the different types of rhinoceros in an engraving, which he could send to his colleagues at home and abroad.

In southern Africa, the British explorer William John Burchell (1781-1863) had penetrated far enough into the unknown interior to find a new species of rhinoceros, larger than the known kind and showing a broad rather than pointed upper lip. He carried a skull back to the coast together with drawings 
made on the spot where he first saw them. Remarkably, and for reasons still poorly understood, he sent word of his greatest discovery not to one of his academic friends in Britain, but to a professor of natural history in Paris, Henri de Blainville (1777-1850), who duly published his letter and drawing of the new Rhinoceros simus.

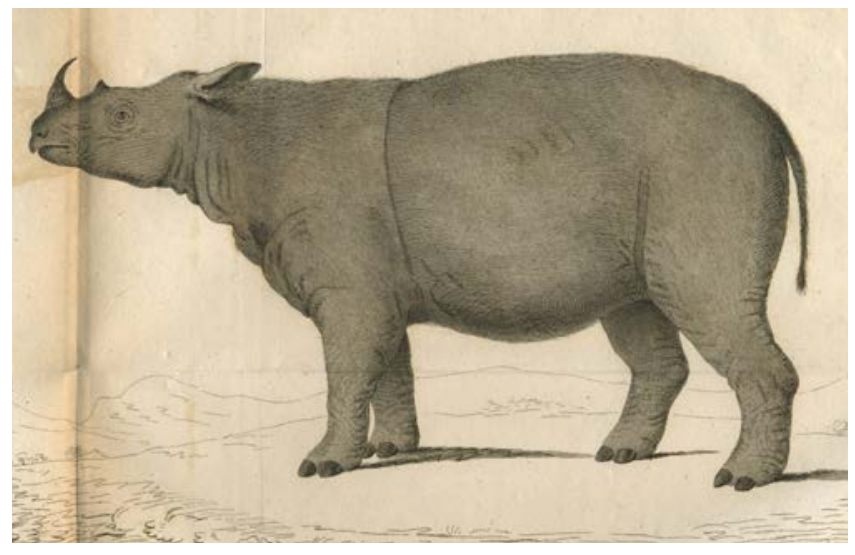

Figure 14.4: The first description of the double horned rhinoceros of Sumatra by William Bell, Surgeon in the Service of the East India Company at Bencoolen. It was published in the Philosophical Transactions of the Royal Society of London in 1793.

Source: From Bell, the Philosophical Transactions of the Royal Society of London in 1793.

Georges Cuvier (1769-1832) was one of the most influential zoologists in Europe in the first quarter of the nineteenth century, where he taught at the university and studied animals in the Jardin des Plantes. When he came to write a general overview of the animal kingdom, it was up to him to evaluate all the different strands of new information which had come to light since the time of Linnaeus. In 1816 he published the first part of his Règne Animal (Animal Kingdom), where, among the pachyderms, he distinguished three living species of rhinoceros: the African two-horned and Indian one-horned types of Linnaeus, to which he added the animal discovered by Bell in Sumatra. We must note the absence of Camper's rhinoceros from Java and Burchell's new African sort, the last of which is explained by the actual date of publication of Cuvier's book, late 1816 rather than 1817 as stated on the title-page. There is still an important role to play by bibliographers to unravel the more intricate puzzles in the development of science.

It must be said that Cuvier appears to have been particularly careful in his definition of the species, not wanting to recognise what in the end might be difficult to separate as a different species on morphological grounds alone. His colleague de Blainville was a little more liberal in a paper published in 1817 where he enumerated three Asian and four African species of rhinoceros. 


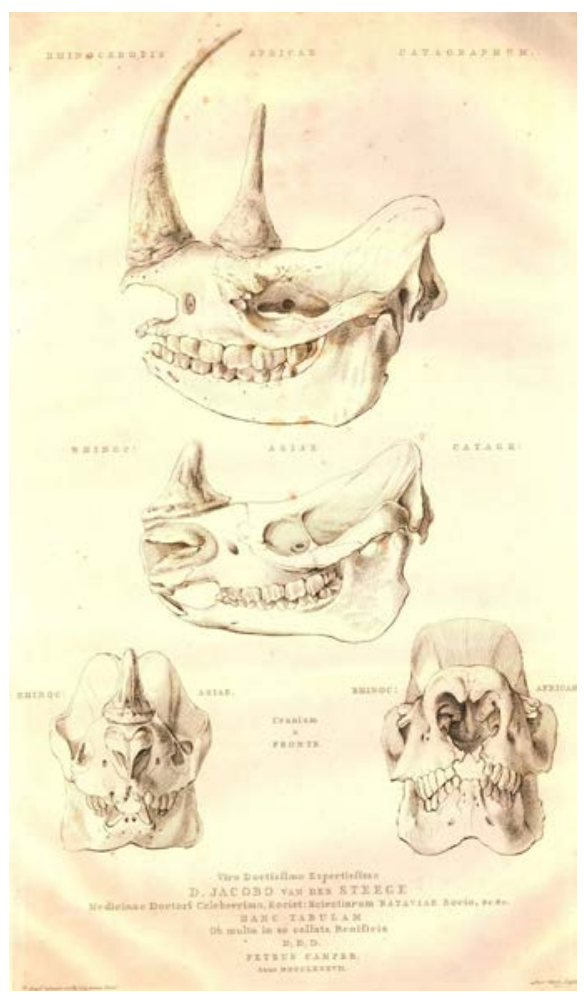

Figure 14.5: Broadside published by the Dutch professor Petrus Camper to show the differences between skulls of a black rhinoceros obtained from the Cape of Good Hope and of a rhinoceros from Java sent to him by Jacob van der Steege. Engraved by Reinier Vinkeles: 'Rhinocerotis Africae Catagraphum', 1787.

Source: British Museum, London.

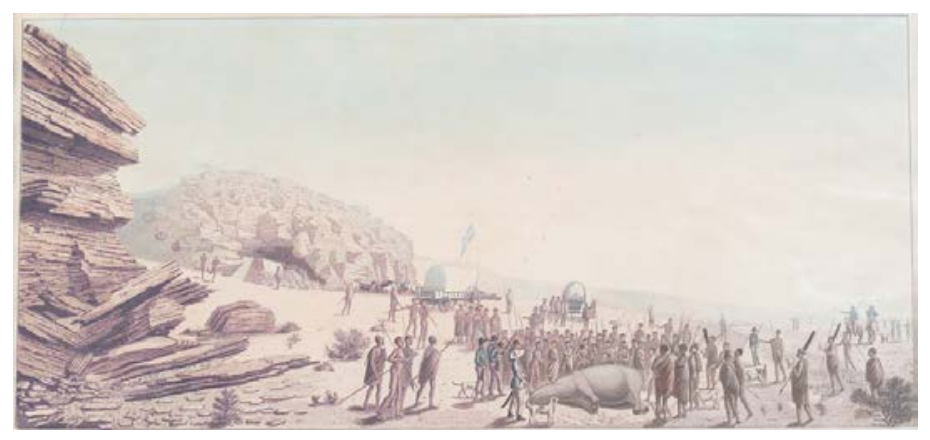

Figure 14.6: Depiction of a rhino hunt at Chué Spring (Heuningvlei) in South Africa by William Burchell in 1812. 
Twelve years later, in 1829, when Cuvier published the second edition of his definitive Règne Animal, he repeated most of the text, but he did add the Javan rhinoceros as a fourth species. He could not do differently, as his brother had described the animal after specimens and a written treatise had been received from Alfred Duvaucel (1793-1824), who had been sent to collect materials on behalf of the museum in Paris. His classification was of course very close to what we would recommend today. I should note, however, the absence of Rhinoceros simus, the white rhinoceros, from his writings, and one wonders why he did not feel inclined to add this as a fifth kind. Maybe the lack of original material at his disposal led to this course of action.

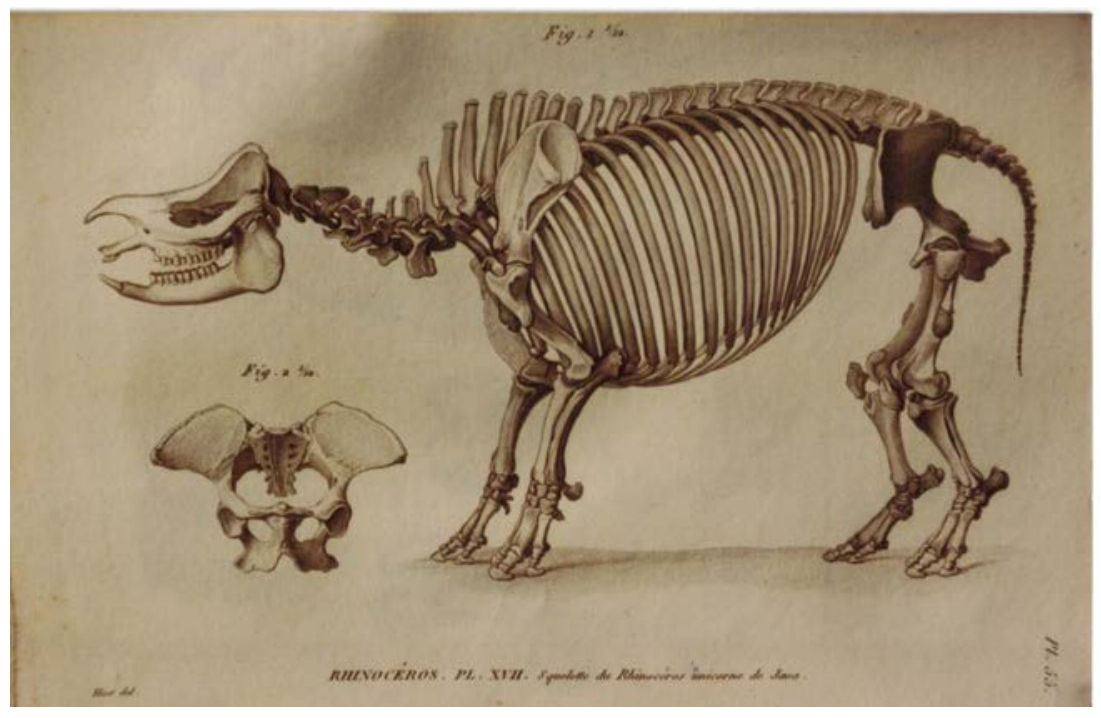

Figure 14.7: Skeleton of the 'Rhinoceros unicorne de Java' in the Paris Museum of Natural History. From Georges Cuvier, Recherches sur les ossemens fossiles (1836), Atlas, pl. 17.

Source: From Georges Cuvier, Recherches sur les ossemens fossiles (1836), Atlas, pl. 17.

\section{Rhino systematics in the time of John Edward Gray}

\section{London, United Kingdom: 1862-1875}

After Cuvier's final edition of the Règne Animal in 1836, the focus of rhino taxonomy definitely shifted to the British sphere of influence. There was a great influx of specimens from all of the range states which had to be diagnosed and 
named. It was a time when new species would be recognised after reading a report in a travel journal or examining just one or even part of a specimen which had just arrived from abroad. Though the aim was obviously to understand the great biodiversity in nature, the result was an array of species and varieties which, if viewed in their totality, was often bewildering.

On 1 June 1835, the British surgeon and naturalist Andrew Smith (1797-1872) was travelling in the African interior near present-day Mafikeng (North-West Province, South Africa) when his hunters alerted him that a different kind of rhinoceros had been shot. Hurrying to the spot to examine this exciting trophy, Smith carefully looked over the animal and that evening, sitting at the campfire, decided to follow the assessment of the assembled crowd. The animal differed from the common black rhino by its greater ferocity and the shape of the horns which were of equal length, and he called it the keitloa. When Smith published his Illustrations of the Zoology of South Africa in 1838, the first instalment started with the new Rhinoceros keitloa, obviously seen as the greatest prize of his expedition into the unknown parts of South Africa.

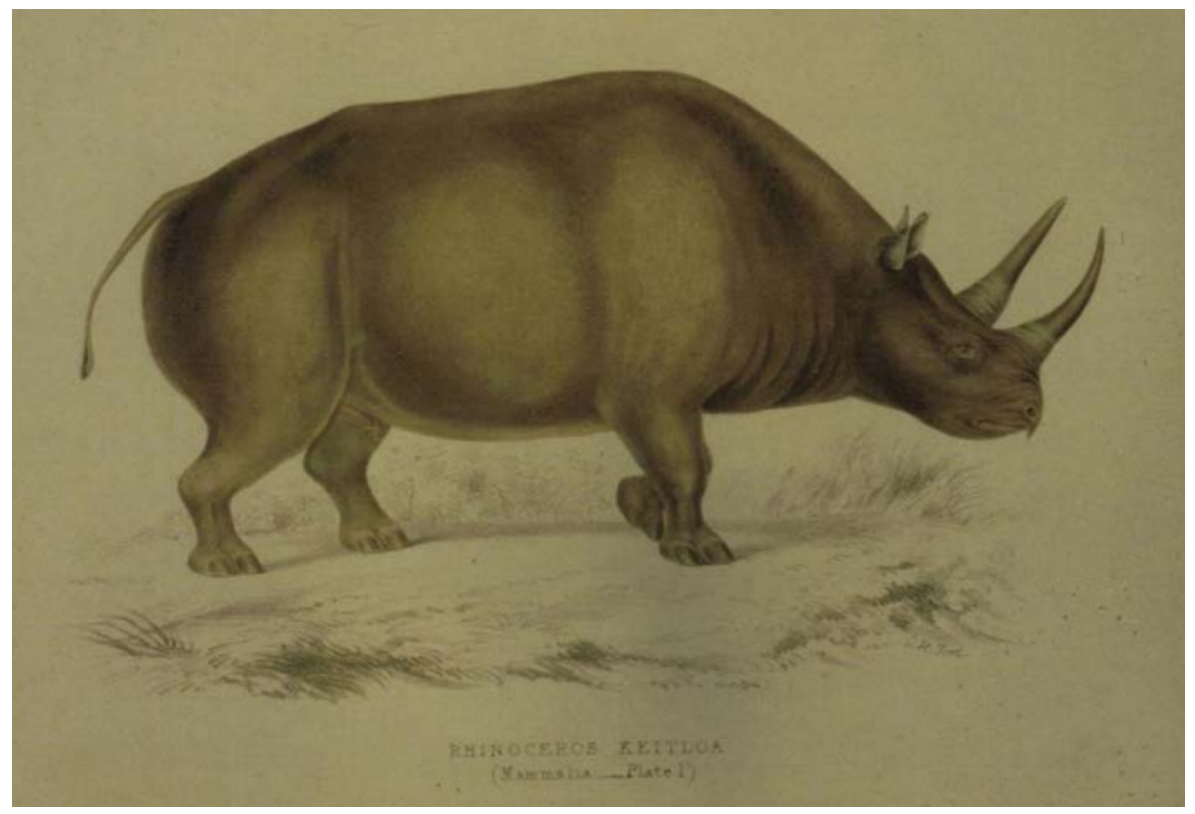

Figure 14.8: Lateral view of black rhinoceros called 'Rhinoceros keitloa' drawn by Gerald Ford for Andrew Smith, Illustrations of Zoology (June 1838), vol. 1, plate 1.

Source: Drawn by Gerald Ford for Andrew Smith, Illustrations of Zoology (June 1838), vol. 1, plate 1. 
The description of this new species of African rhinoceros may not appear particularly momentous, but in a way it opened the flood gates, when an experienced and respected zoologist like Andrew Smith without hesitation was willing to denote horn shape and temperament as characteristics useful enough to warrant specific distinction. In the African bush, this led to widespread speculation and endless discussions. Soon it was not unusual for big game hunters to allude to the existence of six or seven rhino species, all in the southern parts of Africa. Four were almost universally recognised, two types of black (borele and keitloa) and two types of white (mohoohoo and kobaaba). This practice did not remain restricted to the realm of campfire tales, these species were duly named, immortalised and generally accepted from the time of the revisions by John Edward Gray (1800-1875). As the main zoologist in the British Museum, Gray published a series of catalogues of the collections, which were influential and highly regarded. In 1862, Gray had no hesitation to list four African species which he called Rhinoceros bicornis, keitloa, simus and oswellii - and in some ways, he was relatively conservative in his assessment.

In this catalogue of 1862, Gray remained close to the classification of Cuvier by listing the same three species of rhinoceros inhabiting Asia, but he added a fourth one (Rhinoceros crossii) on the basis of an unlocalised strangely shaped horn. However, the time of change had arrived. In a new revision of 1868, Gray had five species of Asian one-horned rhinos as well as one species of Asian twohorned rhino. Edward Blyth (1810-1873) of the Asiatic Museum in Calcutta in 1862 found that skulls differed in broadness and suggested that these characters had specific status. The Secretary of the Zoological Society of London, Philip L. Sclater (1829-1913), compared a two-horned rhino from Chittagong in the London Zoo from 6 February 1872 with another from Malacca which arrived on 2 August 1872. The animals differed, especially in the length of the hairs fringing the ears, and were declared separate species (R. sumatrensis and $R$. lasiotis).

Considering that the above account is a rather watered-down version of the changing taxonomies of rhino species, leaving aside several spurious and even more ill-defined additions to the list, somehow time had come to put some of these distinctions to rest. Maybe it was hardly a coincidence that stabilisation was brought to the field soon after the death of John E. Gray in March 1875. William Henry Flower (1831-1899) had used the extensive collections of the Royal College of Surgeons in London to study the variations in cranial and dental characters. His revision almost miraculously brought new sense to the chaos of conflicting ideas and interpretations. In essence, he reverted back to Cuvier's last views, and recognised just five extant species, in Asia unicornis, sondaicus, sumatrensis, and in Africa bicornis and simus, but was unsure about the status of lasiotis. It was not quite the end to the era of superfluous descriptions and convoluted classifications, but there certainly was a path towards a workable taxonomy. 


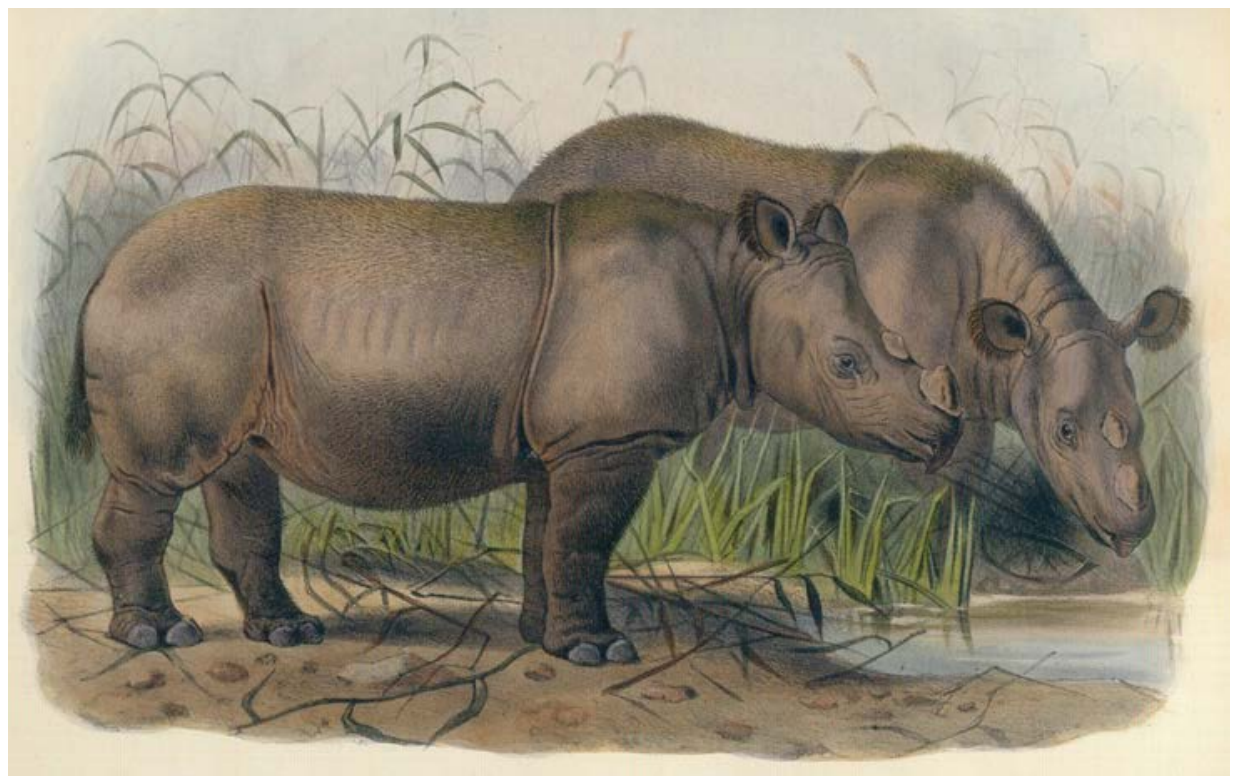

Figure 14.9: Images of the female Sumatran rhino 'Begum' shown in London Zoo from 15 February 1872 to 31 August 1900. She was the type of Rhinoceros lasiotis. From Sclater, On the rhinoceroses now or lately living in the Society's Menagerie (1877), pl. 98.

Source: From Sclater, On the rhinoceroses now or lately living in the Society's Menagerie (1877), pl. 98.

\section{Rhino systematics in the time of Colin Groves}

\section{UK and Australia: From 1965}

The intensity of the debates around rhino systematics in the mid-nineteenth century appears to have scared away any newcomers to the scene. It can truthfully be said that very little change was advocated for just about a century. The only notable exception was the rhinoceros shot by Major Percy Horace Gordon Powell-Cotton (1866-1940) in the Lado Enclave in the central parts of Africa. In this remote and unknown district, he found an animal very much like the white rhinoceros inhabiting regions further south, which differs particularly in the width of the nasal bones. Richard Lydekker (1849-1915) announced the discovery in a short notice tucked away in one of the issues of The Field, a magazine intended for the gentleman interested in field sports. On 22 February 1908 he named the animal Rhinoceros simus cottoni, after the discoverer, using a subspecific epithet, becoming more popular at the time, due to the perceived similarity of the two types of wide-mouthed rhinos. 


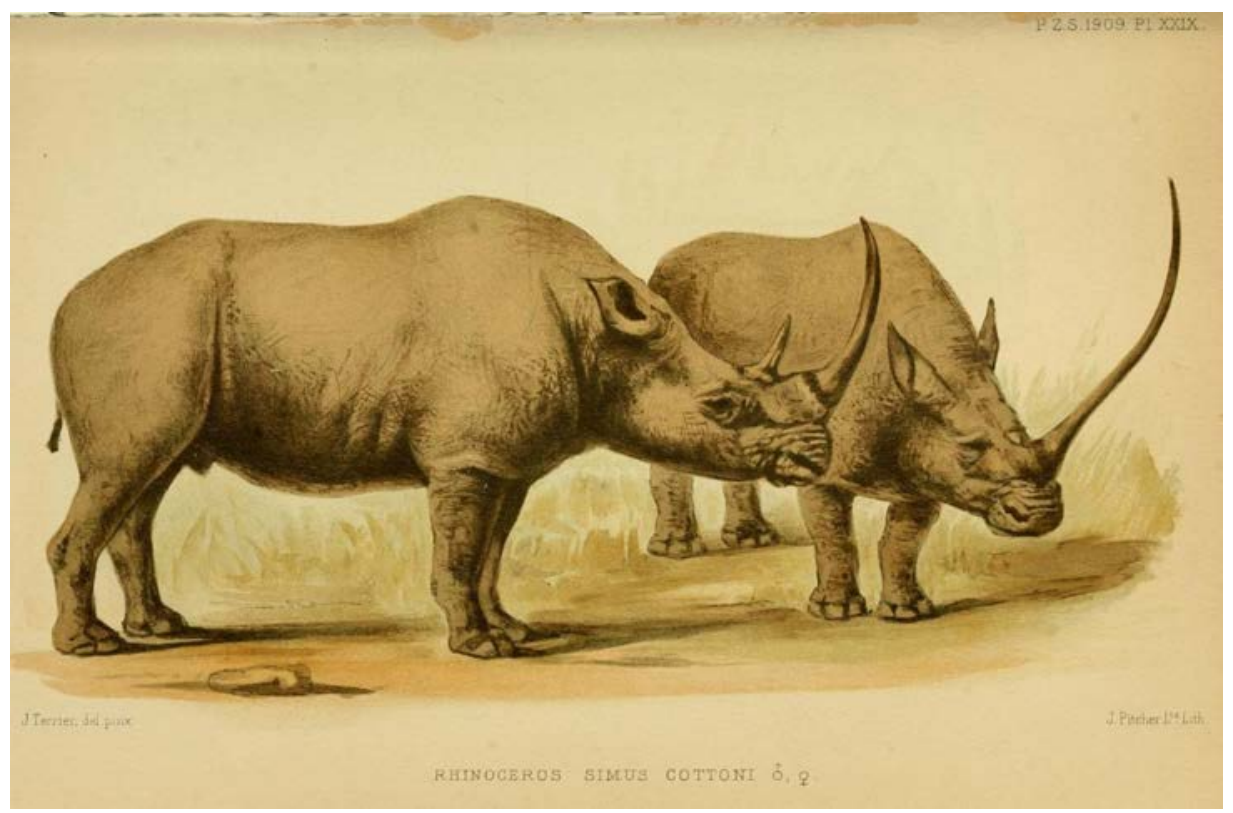

Figure 14.10: Nile rhino from the Lado Enclave in Sudan. Plate drawn by $\mathrm{J}$ Terrier and printed by $\mathrm{J}$ Pitcher. It was used to illustrate the account of this new species by Edouard Louis Trouessart, Le rhinoceros blanc du Soudan (rhinoceros simus cottoni) (1909), plate 1.

Source: From Edouard Louis Trouessart, Le rhinoceros blanc du Soudan (rhinoceros simus cottoni) (1909), plate 1 .

A reasonably stable situation had emerged and remained unchallenged, maybe partly because there was no excitingly new material that warranted a new revision, probably also due to a general lack of interest. In order to compare fossil bones with those of recent African rhinos, Arthur Tindell Hopwood (1897-1969) at the Natural History Museum in London had a fresh look at black rhinoceros systematics. His paper of 1939 had little news to offer, differentiating almost every population examined as a separate subspecies (bicornis, holmwoodi and somaliensis). Inevitably, many new rhino specimens had come to museums and zoos during the century. The African black rhinoceros is widespread and animals from different regions differ in size or colour or temperament or dentition or in a variety of other ways.

The first to undertake a much-needed revision of the species was Ludwig Zukowsky (1888-1965) in Germany, published in Der Zoologische Garten in 1965, which is of course a journal of international rank, but not particularly one where a major taxonomic study would be expected. Zukowsky had been able to compare many living animals during his work in German zoos like Hamburg and Leipzig, to which he added pictures taken in the field and a comprehensive 
survey of literature. Zukowsky's work, although largely ignored, remains in fact one of the major monographs written about a single rhino species. However, he worked in the tradition of taxonomic splitters, who generally used very minor differences to denote new species or subspecies, thereby increasing the number of forms to untenable levels. It is therefore not surprising that Zukowsky recognised 16 subspecies of Diceros bicornis, eight new and others resurrected from older works.

This is where Colin Groves first entered the scene. While pursuing his $\mathrm{PhD}$ studies, he found that the rhinoceros of Borneo differed enough from those of other parts of the range to warrant its description as a new subspecies, which he named after Tom Harrisson (1911-1976), one of those intrepid scholars who combine field work and museum studies. Next, on reading Zukowsky's study of 1965, he was aware that either the book would be totally forgotten and misunderstood, or needed to be put in a context of modern taxonomic theories. With an interest in rhinos which continues to this day, he set out to redress the excessive splitting by Zukowsky and divided the black rhino species in just seven subspecies. It is unfortunate that the international community of conservationists found it hard to cope with this sudden increase in subspecies, from three to seven, as theoretically there had been really no more than three types across the African continent for most of the century. An increase was inevitable though, in view of the fact that the black rhino in eastern and central Africa shows much variation and gradation and sudden morphological changes according to habitats and other patterns.

Groves has made several adjustments to rhino taxonomy during his long career. Together with Claude Guérin, the renowned expert in rhino palaeontology, he looked at data from Indochina and described the material as a subspecies of Rhinoceros sondaicus, correctly resurrecting a forgotten name annamiticus used only once earlier. More recently, while pursuing his belief in the Phylogenetic Species Concept, he has shown that in many ways the two subspecies of white rhino in southern and central Africa differ enough to be separated as species: Ceratotherium simum and Ceratotherium cottoni. This new understanding of their phylogenetic, genetic and biological relationship comes sadly at a time when the last examples in central Africa are being slaughtered by poachers and other opportunists. Ceratotherium cottoni, previously also distinguished in the vernacular as the northern white rhino, really deserves its own name, for which Nile rhinoceros may be one of the better historical choices.

Although the rhino taxonomy proposed by Groves certainly has its critics, there is no published alternative arrangement, which equally takes into account the available museum specimens, genetic material, histories of zoo animals, nomenclatorial rules and a thorough knowledge of the historical as well as current distribution of the rhino species. New insights will certainly come, and taxonomy 
is an evolving field which hopefully one day will become popular again with the increased need to understand global biodiversity. There will always be room for adjustments, but until that time, here is the latest classification of the recent rhinoceroses in Ungulate Taxonomy by Groves and Grubb (2011). Six species are recognised: Rhinoceros unicornis, Rhinoceros sondaicus (three subspecies, one extant), Dicerorhinus sumatrensis (three subspecies, two extant), Diceros bicornis (eight subspecies, four extant), Ceratotherium simum and Ceratotherium cottoni.

\section{Taxonomy in the service of conservation}

One of the reasons to look at the interpretation of rhino diversity over a period of several centuries is to weigh the impact of differing taxonomic interpretations on conservation initiatives. Taxonomy, it is of course recognised, is a field of academic pursuit no different from other scientific disciplines. New facts are constantly added, theories are adjusted, discarded or discovered, and inevitably systematic arrangements will constantly remain in a state of flux. If in 1758 a need had been felt to manage the remaining rhino populations in Africa, there would have been no scientific impediment to translocate anywhere in the continent and breed animals from different regions at will, because only one species was known. If in 1860 similar problems would have been addressed, the managers would have needed to understand a plethora of rather poorly defined species (not even subspecies), which probably would have thwarted the ingenuity of even the best minds given a practical need in the field. And it remains true that changes in systematics can cause any number of awkward or unwanted situations to occur, where animals are translocated to areas outside a range as understood at a given time.

Taxonomy should not obstruct conservation. Conservation should not ignore taxonomy. The goal is to understand biodiversity in all its wonderful facets and to preserve all its elements for future generations. Anybody working for rhino conservation has difficult choices to make on a daily basis. Rhino populations are not just dwindling, they are actively threatened to be wiped out completely. It is a war - to fight people greedily exploiting wildlife, it is a war - to stop encroachments on forest and bush. The possibility that this war will be lost is not unrealistic at all, with ever decreasing resources and ever increasing threats. Maybe the study of taxonomy will soon turn into a study of past biodiversity, gone before it is properly understood. Most people would say that this should not happen, yet only too few are willing to make the sacrifices needed to keep the world stocked with rhinos, and all the other beautiful creatures still precariously kept away from the brink of extinction. 


\section{Acknowledgements}

A long line of people have devoted some of their considerable intellectual or practical expertise to the study and conservation of the rhinoceros. I have had the privilege to meet some and correspond with others, always learning and often enjoying small discoveries in unexpected corners. I acknowledge their expertise and willingness to share their findings. Colin Groves is one of the busy professionals who finds time to guide a younger generation and his advice to me over the years has been invaluable. My wife Sandy and I look back with pleasure on the few times we could meet Colin and Phyll. There is still much to learn about rhinoceros taxonomy, ecology, history, management and conservation, and there is no time to lose as rhinos are under enormous pressure in their wild habitat. In my view, no new study or new conservation project should be undertaken without first understanding what has been done in the distant and recent past in order that we build on the expertise of past generations of dedicated researchers. In the case of the rhinoceros, the Rhino Resource Centre provides an almost unparalled platform which allows access to literature unimpeded by funding or locality, globally available without restriction. I thank all authors who have shared their publications by this means.

\section{References}

Note that all titles are available to view on the website of the Rhino Resource Centre (sponsored by the International Rhino Foundation, SOS Rhino, Rhino Carhire, Save the Rhino International and WWF-Areas).

Bell W. 1793. Description of the double horned rhinoceros of Sumatra. Phil Trans $R$ Soc Lond 1793:3-6, pls. 2-4.

Blyth E. 1862. A memoir on the living Asiatic species of rhinoceros. J Asiatic Soc Bengal 31(2):151-175, pls. 1-4.

Braun A, Groves CP, Grubb P, Yang Qi-Sen, Xia Lin. 2001. Catalogue of the Musée Heude collection of mammal skulls. Acta Zootaxonomica Sinica 26(4):608-660.

Burchell WJ. 1817. Lettre a M. H. de Blainville. In: Blainville HMD de, Lettre de M. W.J. Burchell sur une nouvelle espèce de rhinoceros, et observations sur les différentes espèces de ce genre. Journal de Physique, de Chimie et d'Histoire Naturelle 85:163-168, pl. 1.

Cave AJE, Rookmaaker LC. 1977. Robert Jacob Gordon's original account of the African black rhinoceros. J Zool, Lond 182:137-156, pls. 1-7, figs. 1-2. 
Cuvier G. 1817. Le règne animal distribué d'après son organisation pour servir de base a l'histoire naturelle des animaux et d'introduction à l'anatomie comparée. Paris: Deterville.

Cuvier G. 1829. Le règne animal, 2nd edition. Paris: Deterville et Crochard.

Cuvier G. 1836. Le règne animal, 3rd edition. Bruxelles: Louis Haumann.

Flower WH. 1876. On some cranial and dental characters of the existing species of rhinoceroses. Proc Zool Soc Lond 1876 May 16:443-457, figs. 1-4.

Gentry A, Clutton-Brock J, Groves CP. 2004. The naming of wild animal species and their domestic derivatives. J Archaeol Sci 31:645-651.

Geoffroy Saint-Hilaire E, Cuvier G. 1824. Rhinoceros de Java. In: Geoffroy St. Hilaire E et al. Histoire naturelle des mammifères, vol. 6(45). Paris: Blaise. pp. 1-2, pl. 309.

Gray JE. 1868. Observations on the preserved specimens and skeletons of the Rhinocerotidae in the collection of the British Museum and Royal College of Surgeons, including the description of three new species. Proc Zool Soc Lond 1867:1003-1032, figs. 1-6.

Gray JE, Gerrard E. 1862. Catalogue of the bones of mammalia in the collection of the British Museum. London: Trustees of the British Museum.

Groves CP. 1965. Description of a new subspecies of rhinoceros, from Borneo, Didermocerus sumatrensis harrissoni. Säugetierkundliche Mitteilungen 13(3):128-131.

Groves CP. 1967a. Comment on the proposed decision on the validity of Didermocerus Brookes, 1828. Bull Zool Nomencl 24(5):279.

Groves CP. 1967b. Geographic variation in the black rhinoceros, Diceros bicornis (L, 1758). Z Säugetierk 32(5):267-276, figs. 1-2, tables 1-2.

Groves CP. 1967c. On the rhinoceroses of South-East Asia. Säugetierkundliche Mitteilungen 15(3):221-237, figs. 1-4, tables 1-5.

Groves CP. 1971. Species characters in rhinoceros horns. Z Säugetierk 36(4):238252, figs. 1-22.

Groves CP. 1972. Ceratotherium simum. Mammalian Species no. 8:1-6, figs. 1-5.

Groves CP. 1975. Taxonomic notes on the white rhinoceros Ceratotherium simum (Burchell, 1817). Säugetierkundliche Mitteilungen 23(3):200-212, fig. 1, tables $1-3$. 
Taxonomic Tapestries

Groves CP. 1982a. Asian rhinoceroses: Down but not out. Malayan Naturalist 36(1):11-17, 20-22, figs. 1-4, table 1 .

Groves CP. 1982b. The skulls of Asian rhinoceroses, wild and captive. Zoo Biology 1:251-261, tables 1-4.

Groves CP. 1983. Phylogeny of the living species of rhinoceros. Z Zool Syst Evol 21(4):293-313, figs. 1-11.

Groves CP. 1993a. Bad medicine for wildlife. The Skeptic 13(1):12-14.

Groves CP. 1993b. Testing rhinoceros subspecies by multivariate analysis. In: Ryder OA, editor. Rhinoceros biology and conservation: Proceedings of an international conference. San Diego, USA: San Diego, Zoological Society. pp. 92-100, figs. $1-5$.

Groves CP. 1995a. A comment on Haryono et al.'s Report. Asian Rhinos 2:9.

Groves CP. 1995b. What is wrong with the captive population of Sumatran rhinos? Asian Rhinos 2:12.

Groves CP. 1995c. Why the Cat Loc (Vietnam) rhinos are Javan. Asian Rhinos 2:8-9, fig. 1.

Groves CP. 1997. Die Nashörner - Stammesgeschichte und Verwandtschaft. In: Anonymous. Die Nashörner: Begegnung mit urzeitliche Kolossen. Fuert: Filander Verlag. pp. 14-32, figs. 1-5.

Groves CP. 2003. Taxonomy of ungulates of the Indian subcontinent. J Bombay Nat Hist Soc 100(2/3):341-362.

Groves CP. 2008a. Extended family: Long-lost cousins. A personal look at the history of primatology. Arlington, VA: Conservation International.

Groves CP. 2008b. Review of L.C. Rookmaaker, Encounters with the African rhinoceros. J Mammal 89(6):1570.

Groves CP, Chakraborty S. 1983. The Calcutta collection of Asian rhinoceroses. Rec Zool Surv India 80:251-263, tables 1-2.

Groves CP, Fernando P, Robovsky J. 2010. The sixth rhino: A taxonomic reassessment of the critically endangered northern white rhinoceros. PLoS One 5(4) e9703:1-15

Groves CP, Grubb P. 2011. Ungulate taxonomy. Baltimore: Johns Hopkins University Press. 
Groves CP, Guérin C. 1980. Le Rhinoceros sondaicus annamiticus d'Indochine: Distinction taxinomique et anatomique; rélations phylétiques. Géobios 13(2):199-208, figs. 1-4, tables 1-2.

Groves CP, Kurt F. 1972. Dicerorhinus sumatrensis. Mammalian Species 21:1-6, figs. $1-4$.

Groves CP, Leslie Jr. DM. 2011. Rhinoceros sondaicus (Perissodactyla: Rhinocerotidae). Mammalian Species 43 (887):190-208.

Groves CP, Robovsky, J. 2011. African rhinos and elephants: Biodiversity and its preservation. Pachyderm 50:69-71.

Hillman Smith K, Groves CP. 1994. Diceros bicornis. Mammalian Species 455:1-8, figs. $1-3$.

Laurie WA, Lang EM, Groves CP 1983. Rhinoceros unicornis. Mammalian Species 211:1-6, figs. 1-3.

Linnaeus C. 1758. Systema naturae per regna tria naturae, secundum classes, ordines, genera, species, cum characteribus, differentiis, synonymis, locis. Editio decima, reformata. Holmiae: Laurentii Salvii.

Lydekker R. 1908. The white rhinoceros. Field 22 February 1980 (2878:319).

Prins HHT. 1990. Geographic variation in skulls of the nearly extinct small black rhinoceros Diceros bicornis michaeli in northern Tanzania. Z Säugetierk 55:260-269, figs. 1-3, tables 1-5.

Robovsky J, Fernando P, Groves CP. 2010. Misto peti nosorozcu sest. Novy druk, ktery uz viasne neesistuje. Vesmir 89:368-371, figs. 1-4.

Rookmaaker LC. 1978. Two collections of rhinoceros plates compiled by James Douglas and James Parsons in the eighteenth century. Journal of the Society for the Bibliography of Natural History 9(1):17-38, figs. 1-7

Rookmaaker LC. 1982. The type locality of the Javan Rhinoceros (Rhinoceros sondaicus Desmarest, 1822). Z Säugetierk 47(6):381-382

Rookmaaker LC. 1983a. Bibliography of the rhinoceros: An analysis of the literature on the recent rhinoceroses in culture, history and biology. Rotterdam and Brookfield: A.A. Balkema.

Rookmaaker LC. 1983b. Historical notes on the taxonomy and nomenclature of the recent Rhinocerotidae (Mammalia, Perissodactyla). Beaufortia 33(4):3751, figs. 1-4.

Rookmaaker LC. 1983c. Jamrachs Rhinozeros. Bongo, Berlin 7:43-50, fig. 1 
Taxonomic Tapestries

Rookmaaker LC. 1984. The taxonomic history of the recent forms of Sumatran Rhinoceros (Dicerorhinus sumatrensis). $J$ Malays Branch $R$ Asiatic Soc 57(1):12-25, figs. 1-6.

Rookmaaker LC. 1989. The zoological exploration of Southern Africa 1650-1790. Rotterdam and Brookfield: A.A. Balkema.

Rookmaaker LC. 1998. The sources of Linnaeus on the rhinoceros. Sven Linnesallskap Arsskr 1996/97:61-80, figs. 1-15.

Rookmaaker LC. 1999. Specimens of rhinoceros in European collections before 1778. Sven Linnesallskap Arsskr 1998/99:59-80, figs. 1-7.

Rookmaaker LC. 2003a. The last white rhinoceros in Zimbabwe. Pachyderm 35:100-114, figs. 1-8.

Rookmaaker LC. 2003b. Why the name of the white rhinoceros is not appropriate. Pachyderm 34:88-93, pl. 1.

Rookmaaker LC. 2004. Rhinoceros rugosus - a name for the Indian rhinoceros. $J$ Bombay Nat Hist Soc 101(2):308-310.

Rookmaaker LC. 2005. Review of the European perception of the African rhinoceros. J Zool, Lond 265:365-376, figs. 1-9.

Rookmaaker LC. 2005. The black rhino needs a taxonomic revision for sound conservation. International Zoo News 52(5):280-282.

Rookmaaker LC. 2008. Encounters with the African rhinoceros: A chronological survey of bibliographical and iconographical sources on rhinoceroses in southern Africa from 1795 to 1875: Reconstructing views on classification and changes in distribution. Münster: Schuling Verlag.

Rookmaaker LC. 2010. The sixth living rhino species? International Zoo News 57(3): 171 .

Rookmaaker LC. 201la. A review of black rhino systematics proposed in Ungulate Taxonomy by Groves and Grubb (2011) and its implications for rhino conservation. Pachyderm 50:72-76.

Rookmaaker LC. 2011b. The early endeavours by Hugh Edwin Strickland to establish a code for zoological nomenclature in 1842-1843. Bull Zool Nomencl 68(1):29-40.

Rookmaaker LC, editor. 2013. www.rhinoresourcecentre.com. (accessed 2013). 
Rookmaaker LC, Kraft R. 2011. The history of the unique type of Rhinoceros cucullatus, with remarks on observations in Ethiopia by James Bruce and William Cornwallis Harris (Mammalia, Rhinocerotidae). Spixiana 34(1):133134, figs. 1-8.

Rookmaaker LC, Groves CP. 1978. The extinct Cape rhinoceros, Diceros bicornis bicornis (Linnaeus, 1758). Säugetierkundliche Mitteilungen 26(2):117-126, fig. 1 , tables $1-3$.

Rookmaaker LC, Visser RPW. 1982. Petrus Camper's study of the Javan rhinoceros (Rhinoceros sondaicus) and its influence on Georges Cuvier. Bijdragen tot de Dierkunde, Amsterdam 52(2):121-136, figs. 1-8.

Sclater PL. 1872. Notes on Propithecus bicornis and Rhinoceros lasiotis. Ann Mag Nat Hist (4)10:298-299.

Sclater PL. 1877. On the rhinoceroses now or lately living in the Society's Menagerie. Trans Zool Soc Lond 9:645-660, pls. 95-99, figs. 1-9.

Smith A. 1838. Illustrations of the zoology of South Africa; consisting chiefly of figures and descriptions of the objects of natural history collected during an expedition into the interior of South Africa, vol. 1: Mammalia, part 1. London: Smith, Elder and Co.

Toit $\mathrm{R}$ du. 1987. The existing basis for subspecies classification of black and white rhinos. Pachyderm 9:3-5.

Trouessart E-L. 1908. Le rhinoceros blanc du Bahr-el-Gazal. La Nature, revue des sciences et de leurs applications aux arts et à l'industrie 37:50-53, figs. 1-2.

Trouessart E-L. 1909. Le rhinoceros blanc du Soudan (rhinoceros simus cottoni). Proc Zool Soc Lond 1909 February 16:198-200.

Zukowsky L. 1965. Die Systematik der Gattung Diceros Gray, 1821. Zoologische Garten 30:1-178, figs. 1-8. 
This text is taken from Taxonomic Tapestries: The Threads of Evolutionary, Behavioural and Conservation Research, edited by Alison M Behie and Marc F Oxenham, published 2015 by ANU Press, The Australian National University, Canberra, Australia. 